\title{
DAMPAK TERAPI INTRAVENA PADA BALITA BERDASAR VIP (VISUAL INFUSION PHLEBITIS) SCORE
}

\author{
(The Effects of Intravenous Therapy in Infants Based on the \\ VIP (Visual Infusion Phlebitis) Score)
}

\author{
Hernantika Rahmawati \\ Program Studi DIII Keperawatan Blitar. Poltekkes Kemenkes Malang. \\ e-mail : hernantika1212@gmail.com
}

\begin{abstract}
Patient safety at hospital is system that nursing care given more safe. When patient at hospital they may got nosocomial enfection, and some medical procedure have an effect for them, for example intravenous therapy lead to causes of phlebitis. The purpose of this studiy was to determine the effects of intravenous therapy in infants based on the VIP (Visual Infusion phlebitis) score. Method: The research design was descriptive study. The population in this study are 38infants who received intravenous therapy. Samples are 30 infants by using convenience sampling, research on March 2014 at Nusaindah room Mardi Waluyo Blitar Hospital. Result : Research found a total of 27 infants no signs of phlebitis, as much as 2 toddlers possibility of early signs phlebitis, and 1 toddler stage beginning phlebitis. Discussion: We expected that nurse will enhance observation of the effects of intravenous therapy.
\end{abstract}

Keywords : Intravenous Therapy, VIP (Visual Infusion Phlebitis)

Keselamatan pasien (patient safety) di rumah sakit merupakan suatu sistem di mana rumah sakit membuat asuhan pasien lebih aman (Depkes RI, 2006). Keselamatan pasien sangat penting untuk menghindari Kejadian Tidak Diharapkan (KTD), seperti infeksi nosokomial. Darmadi (2008) menyatakan bahwa infeksi nosokomial adalah infeksi yang didapat oleh penderita ketika penderita dalam proses asuhan keperawatan di rumah sakit. Terapi yang diberikan bermacam-macam, salah satunya adalah pemberian terapi intravena. Pada pemberian terapi intravena, dampak lokal sering terjadi dibandingkan dengan dampak sistemik. Salah satu dampak lokal yaitu phlebitis. Phlebitis didefinisikan sebagai inflamasi vena yang disebabkan oleh iritasi kimia maupun mekanik. Hal ini dikarakteristikkan dengan adanya daerah yang memerah dan hangat di sekitar daerah penusukan atau sepanjang vena, serta pembengkakan (Brunner \& Suddarth, 2002).

Di Indonesia belum ada angka yang pasti tentang prevalensi phlebitis, mungkin disebabkan karena penelitian yang berkaitan dengan terapi intravena dan publikasinya masih jarang. Angka standar phlebitis yang direkomendasikan oleh INS (Infusion Nurses Society) adalah 5\%. Angka kejadian infeksi nosokomial (phlebitis) di Instalasi Rawat Inap RS Universitas Hasanuddin selama 4 triwulan tahun 2012 yaitu $14,7 \%$; 3,7\%; 4,48\%; dan $3,7 \%$ sehingga rata-rata kejadian infeksi nosokomial (phlebitis) sebanyak 6,64\%. Angka kejadian ini melewati standar KMK (Keputusan Kementerian Kesehatan) No. 129 Tahun 2008 sebesar $\leq 1,5 \%$ (Nur, Noor, \& Irwandy: 2013).

Studi pendahuluan yang dilakukan peneliti pada tanggal 18 Desember 2013 di ruang rawat inap Nusaindah RSD Mardi Waluyo Kota Blitar, didapatkan data dari hasil wawancara petugas kesehatan bahwa tidak ada angka pasti dampak terapi intravena khususnya phlebitis, karena tidak adanya dokumentasi deteksi dini tanda dan gejala dampak terapi intravena. Tetapi secara umum gejala yang sering muncul yaitu bengkak di area penusukan intravena, dialami oleh pasien usia di bawah 6 tahun, karena dipengaruhi oleh obat dengan konsentrasi pekat dan aktivitas pasien kurang kooperatif. Upaya yang sudah dilakukan untuk mencegah terjadinya dampak terapi intravena 
adalah dilakukannya penggantian tempat penusukan intravena setiap 72 jam. Sebelum 72 jam, jika ada pembengkakan di area penusukan, saat itu juga diganti tempat penusukan intravena.

Dampak dari tindakan pemberian terapi intravena (phlebitis) merupakan masalah yang serius, namun tidak menyebabkan kematian. Tetapi dampak yang sering terlihat yaitu terhambatnya kelangsungan pemberian terapi intravena dan kecemasan pasien atau keluarga. Terutama kecemasan keluarga dengan balita yang mendapatkan terapi intravena. Menurut Kusyati dalam Aprillin (2011) menyatakan bahwa, seharusnya selama pemberian terapi cairan intravena pasien harus mendapat pengawasan dan observasi yang ketat. Alat ukur untuk mengobservasi tanda phlebitis menggunaan skala Visual Infusion Phlebitis. Berdasarkan dari latar belakang tersebut penulis ingin meneliti tentang "Dampak terapi intravena pada balita berdasar VIP (Visual Infusion Phlebitis) score di ruang Nusaindah RSD Mardi Waluyo Kota Blitar".

Rumusan masalahnya adalah Bagaimanakah dampak terapi intravena pada balita berdasar VIP (Visual Infusion Phlebitis) score di ruang Nusaindah RSD Mardi Waluyo Kota Blitar.

Tujuan penelitian ini adalah mengetahui dampak terapi intravena pada balita berdasar VIP (Visual Infusion Phlebitis) score.

Manfaat penelitian bagi instansi kesehatan adalah dapat digunakan sebagai HASIL PENELITIAN

Karakteristik responden tertera pada tabel di bawah.

Tabel 1. Pemasangan intravena terakhir dengan dampak terapi intravena

\begin{tabular}{ccccccc}
\hline & \multicolumn{5}{c}{ Dampak Terapi Intravena } \\
\cline { 2 - 7 } $\begin{array}{c}\text { Pemasangan } \\
\text { IVterakhir }\end{array}$ & $\begin{array}{c}\text { Tidak ada } \\
\text { tanda phlebitis }\end{array}$ & $\begin{array}{c}\text { Kemungkinan } \\
\text { tanda dini } \\
\text { phlebitis }\end{array}$ & $\begin{array}{c}\text { Stadium permulaan } \\
\text { phlebitis }\end{array}$ \\
\cline { 2 - 7 } & $\mathbf{f}$ & $\mathbf{\%}$ & f & \% & f \\
\hline 1 hari & 7 & 23,3 & 0 & 0 & 0 & 0 \\
$\mathbf{2}$ hari & 16 & 53,3 & 0 & 0 & 0 & 0 \\
3 hari & 3 & 10 & 1 & 3,3 & 1 & 3,3 \\
4 hari & 1 & 3,3 & 1 & 3,3 & 0 & 0 \\
\hline
\end{tabular}

Tabel 2. Tempat pemasangan intravena dengan dampak terapi intravena tambahan sumber informasi serta pertimbangan untuk mengetahui dampak terapi intravena berdasarkan VIP (Visual Infusion Phlebitis) score. Manfaat penelitian bagi institusi pendidikan dapat digunakan sebagai tambahan pustaka mengenai dampak terapi intravena berdasarkan VIP (Visual Infusion Phlebitis) score. Sedangkan Manfaat penelitian bagi selanjutnya dapat Memberikan gambaran dampak terapi intravena berdasarkan VIP (Visual Infusion Phlebitis) score, sehingga dapat digunakan sebagai data dasar dan pedoman untuk penelitian selanjutnya.

\section{BAHAN DAN METODE}

Desain penelitian deskriptif yaitu dengan subyek dalam penelitian adalah balita yang mendapat terapi intravena sebanyak 30 balita di ruang Nusaindah RSD Mardi Waluyo Kota Blitar.

Penelitan ini menggunakan teknik convinience sampling. Variabel pada penelitian ini adalah dampak terapi intravena (phlebitis). Analisa data meliputi data umum dan data khusus. Data umum yaitu jenis kelamin, umur, lamanya balita dirawat, pemasangan intravena terakhir, tempat pemasangan intravena, ukuran jarum, jenis cairan infus, jumlah cairan infus yang habis, aktivitas balita, dan tindakan pembidaian tempat pemasangan intravena. Sedangkan data khusus yaitu dampak terapi intravena yang dianalisa menggunakan metode observasi VIP (Visual Infusion Phlebitis) score.
Dampak Terapi Intravena

Tempat Pemasangan Intravena

\begin{tabular}{|c|c|c|c|}
\hline \multirow[b]{2}{*}{$\begin{array}{c}\text { Tempat Pemasangan } \\
\text { Intravena }\end{array}$} & \multicolumn{3}{|c|}{ Dampak Terapi Intravena } \\
\hline & $\begin{array}{c}\text { Tidak ada } \\
\text { tanda phlebitis }\end{array}$ & $\begin{array}{l}\text { Kemungkinan } \\
\text { tanda dini }\end{array}$ & $\begin{array}{c}\text { Stadium permulaan } \\
\text { phlebitis }\end{array}$ \\
\hline
\end{tabular}




\begin{tabular}{lcccccc}
\hline & \multicolumn{7}{c}{ phlebitis } \\
\cline { 2 - 7 } & f & \% & f & \% & f & \% \\
\hline Tangan kanan & 10 & 33,3 & 0 & 0 & 0 & 0 \\
Tangan kiri & 17 & 56,7 & 2 & 6,7 & 1 & 3,3 \\
\hline
\end{tabular}

Tabel 3. Aktivitas balita dengan dampak terapi intravena

\begin{tabular}{|c|c|c|c|c|c|c|}
\hline \multirow{3}{*}{ Aktivitas balita } & \multicolumn{6}{|c|}{ Dampak Terapi Intravena } \\
\hline & \multicolumn{2}{|c|}{$\begin{array}{c}\text { Tidak ada } \\
\text { tanda phlebitis }\end{array}$} & \multicolumn{2}{|c|}{$\begin{array}{c}\text { Kemungkinan } \\
\text { tanda dini } \\
\text { phlebitis }\end{array}$} & \multicolumn{2}{|c|}{$\begin{array}{c}\text { Stadium permulaan } \\
\text { phlebitis }\end{array}$} \\
\hline & f & $\%$ & $\mathbf{f}$ & $\%$ & $\mathbf{f}$ & $\%$ \\
\hline $\begin{array}{l}\text { Diam/ berbaring di } \\
\text { tempat tidur }\end{array}$ & 18 & 60,0 & 0 & 0 & 0 & 0 \\
\hline Jalan sendiri ke toilet & 4 & 13,3 & 1 & 3,3 & 0 & 0 \\
\hline Naik turun tempat tidur & 5 & 16,7 & 1 & 3,3 & 1 & 3,3 \\
\hline
\end{tabular}

Tabel 4. Tindakan pembidaian tempat pemasangan intravena dengan dampak terapi intravena

\begin{tabular}{lcccccc}
\hline & \multicolumn{5}{c}{ Dampak Terapi Intravena } \\
\cline { 2 - 7 } Tindakan pembidaian & $\begin{array}{c}\text { Tidak ada } \\
\text { tanda phlebitis }\end{array}$ & $\begin{array}{c}\text { Kemungkinan } \\
\text { tanda dini } \\
\text { phlebitis }\end{array}$ & $\begin{array}{c}\text { Stadium permulaan } \\
\text { phlebitis }\end{array}$ \\
\cline { 2 - 7 } & $\mathbf{f}$ & $\%$ & f & \% & f & $\%$ \\
\hline Ya & 24 & 80,0 & 0 & 0 & 1 & 3,3 \\
Tidak & 3 & 10 & 2 & 6,7 & 0 & 0 \\
\hline
\end{tabular}

Berdasarkan hasil penelitian didapatkan bahwa dari 29 responden, hampir setengahnya $(44,8 \%)$ responden berjenis kelamin laki - laki, hampir setengahnya $(48 \%)$ responden telah tinggal di panti selama 3-5 tahun, hampir seluruhnya $(82 \%)$ responden beragama islam, sebagian besar $(65 \%)$ responden bekerja selain pegawai swasta dan wiraswasta, sebagian besar $(82 \%)$ responden beribadah di sarana ibadah mushola dan sebagian besar $(55,2 \%)$ responden sering mengikuti bimbingan keagamaan serta memiliki pemenuhan kebutuhan spiritual yang baik.

\section{PEMBAHASAN}

Berdasarkan hasil penelitian menunjukan bahwa dampak terapi intravena pada 30 balita yang diobservasi, sebanyak 27 balita dengan skor 0 ditandai dengan keadaan tempat penusukan intravena tampak sehat yang menunjukkan bahwa tidak ada tanda phlebitis, sebanyak 2 balita dengan skor 1 ditandai dengan nyeri tempat penusukan intravena yang menunjukkan kemungkinan tanda dini phlebitis, dan 1 balita dengan skor 2 ditandai dengan nyeri tempat penusukan intravena serta terdapat pembengkakan yang menunjukkan stadium permulaan phlebitis. Tanda dampak terapi intravena diobservasi menggunakan pengamatan visual dengan VIP score didapat dari Andrew Jackson tahun 1997 yang diterjemahkan sendiri. Dampak terapi intravena atau phlebitis merupakan suatu keadaan yang diakibatkan dari tindakan pemberian terapi intravena, dapat terjadi karena dipengaruhi oleh beberapa faktor, baik dari peralatan yang digunakan atau perawatan terapi intravena.

Balita dengan stadium permulaan phlebitis tersebut berjenis kelamin laki-laki, umur 36 bulan, balita dirawat selama 3 hari, pemasangan intravena terakhir adalah 3 hari yang lalu, tempat pemasangan infus di tangan sebelah kiri menggunakan ukuran jarum $22 \mathrm{G}$ serta dilakukan tindakan pembidaian tempat pemasangan intravena, jenis cairan infus adalah cairan isotonis, jumlah cairan infus yang sudah habis digunakan sebanyak $2500 \mathrm{cc}$, dan balita sering naik turun tempat tidur. Balita yang kemungkinan tanda dini phlebitis berjenis kelamin perempuan, umur 54 bulan, balita dirawat selama 4 hari, pemasangan intravena terakhir adalah 4 hari yang lalu, tempat 
pemasangan intravena di tangan sebelah kiri menggunakan ukuran jarum $22 \mathrm{G}$ serta tidak dilakukan tindakan pembidaian tempat pemasangan intravena, jenis cairan infus adalah cairan isotonis, jumlah cairan infus yang sudah habis digunakan sebanyak $2500 \mathrm{cc}$, dan aktifitas yang sering dilakukan balita yaitu naik turun tempat tidur. Sedangkan salah satu balita yang juga kemungkinan tanda dini phlebitis, berjenis kelamin perempuan, umur 48 bulan, balita dirawat selama 3 hari, pemasangan intravena terakhir adalah 3 hari yang lalu, tempat pemasangan intravena di tangan sebelah kiri menggunakan ukuran jarum $22 \mathrm{G}$ serta tidak dilakukan tindakan pembidaian tempat pemasangan intravena, jenis cairan infus adalah cairan isotonis, jumlah cairan infus yang sudah habis digunakan sebanyak $2500 \mathrm{cc}$, dan balita sering berjalan sendiri jika ke toilet.

Berdasarkan hasil penelitian jenis cairan intravena pada balita didapatkan sebanyak $63 \%$ atau 19 balita mendapat cairan KA-EN 3B. Jenis cairan KA-EN 3B, RL, dan Glukosa 5\% adalah cairan isotonis. Jenis cairan infus yang digunakan oleh ketiga balita yang menunjukkan dampak terapi intravena adalah cairan isotonis. Cairan KA-EN 3B $500 \mathrm{~mL}$ berisi Dextrosa 13.500 g; Sodium Chloride 0,875 g; Potassium Chloride $0,750 \mathrm{~g}$; Sodium $50 \mathrm{mEq} / \mathrm{L}$; Lactate $20 \mathrm{mEq} / \mathrm{L}$. Cairan KA-EN 3B dengan osmolaritas $290 \mathrm{mOsm} / \mathrm{L}$. Cairan intravena RL dengan osmolaritas $274 \mathrm{mOsm} / \mathrm{L}$ dan Glukosa $5 \%$ dengan osmolaritas $252 \mathrm{mOsm} / \mathrm{L}$. Menurut pendapat Brunner \& Suddart (2002:282) menyatakan bahwa cairan yang diklasifikasikan isotonik mempunyai osmolalitas total yang mendekati cairan ekstraseluler dan tidak menyebabkan sel darah merah mengkerut atau membengkak. Perawat juga harus mempertimbangkan osmolalitas suatu larutan, tetap mengingat bahwa osmolalitas plasma adalah kira-kira $300 \mathrm{mOsm} / \mathrm{L}$ (SI:300 mmol/L). Jika memberikan cairan parenteral, penting untuk memantau respon pasien terhadap cairan. Perawat harus mempertimbangkan volume cairan, kandungan cairan, dan status klinis pasien.

\section{Pemasangan Intravena Terakhir Dengan Dampak Terapi Intravena}

Berdasarkan hasil penelitian didapatkan bahwa pemasangan intravena terakhir atau lama pemasangan intravena pada 30 balita yaitu paling banyak selama 2 hari. Balita yang mendapat skor 0 atau tidak ada tanda phlebitis sebanyak 90\% (27) balita, diantaranya yaitu sebanyak 3 balita yang pemasangan intravena terakhir selama 3 hari bahwa balita dilakukan tindakan pembidaian tempat pemasangan intravena dan aktivitas balita adalah diam atau berbaring di tempat tidur. Sedangkan 1 balita yang pemasangan intravena terakhir selama 4 hari, balita tersebut juga dilakukan tindakan pembidaian tempat pemasangan intravena. Sebanyak $6,7 \%$ (2) balita yang mendapat skor 1 atau kemungkinan terjadi tanda dini phlebitis, pemasangan intravena terakhir selama 3 hari dan 4 hari. Sebanyak 3,3\% (1) balita dengan skor 2 atau stadium permulaan phlebitis, pemasangan intravena terakhir selama 3 hari. Menurut pendapat Brunner \& Suddart (2002) bahwa mengganti kanula IV perifer setiap 48 sampai 72 jam, atau sesuai indikasi. Pemasangan intravena lebih dari 72 jam menunjukkan tanda gejala dampak terapi intravena. Data tersebut menunjukkan bahwa lama penyisipan intravena sangat berpengaruh terhadap terjadinya phlebitis. Sebelum 72 jam tempat penusukan intravena pada balita dapat diganti untuk mencegah terjadinya dampak terapi intravena. Tempat penusukan intravena harus diobservasi setiap hari, karena jika terdapat gejala tersebut seperti kemerahan atau nyeri tempat penusukan dapat segera dilakukan tindakan perawatan tempat pemasangan intravena.

\section{Tempat Pemasangan Intravena Dengan Dampak Terapi Intravena}

Berdasarkan hasil penelitian tempat pemasangan intravena pada balita didapatkan hasil sebanyak 33,3 (10) balita terpasang intravena di tangan sebelah kanan. Balita terpasang intravena di tangan sebelah kiri sebanyak 56,7 (17) balita yaitu tidak ada tanda phlebitis, sebanyak $6,7 \%$ (2) balita kemungkinan terdapat tanda dini phlebitis dan sebanyak 33,3 (1) balita dengan stadium pertengahan phlebitis. Menurut Brunner \& Suddart (2002:283) menyatakan bahwa banyak tempat yang digunakan untuk terapi intravena, tetapi kemudahan akses dan potensi bahaya berbeda di antara tempat-tempat ini. Vena di ekstremitas dipilih sebagai lokasi perifer dan pada mulanya merupakan tempat satu-satunya yang digunakan oleh perawat. Karena vena ini relatif aman dan mudah dimasuki, vena-vena di ekstremitas atas paling sering digunakan. 
Idealnya kedua lengan dan tangan harus diinspeksi dengan cermat sebelum tempat pungsi vena spesifik dipilih. Lokasi harus dipilih yang tidak mengganggu mobilisasi. Tempat yang paling distal dari lengan atau tangan umumnya digunakan pertama kali sehingga IV yang berikutnya dapat dilakukan kearah yang atas. Hal-hal berikut menjadi pertimbangan ketika memilih tempat penusukan vena; kondisi vena, jenis cairan atau obat yang akan diinfuskan, dan lamanya terapi. Pemasangan intravena di tangan kanan atau kiri tidak menjadi suatu masalah. Biasanya tangan kiri cenderung pasif digunakan dan tangan kanan sering untuk pergerakan. Tetapi yang sering terlihat pada balita cenderung aktif menggunakan kedua tangan, sehingga dapat menimbulkan pergerakan tempat pemasangan intravena di tangan kanan atau tangan kiri.

\section{Aktivitas Balita Dengan Dampak Terapi Intravena}

Berdasarkan hasil penelitian tentang aktivitas balita didapatkan bahwa sebanyak 60\% (18) balita yaitu diam atau berbaring di tempat tidur. Aktivitas balita yang naik turun tempat tidur sebanyak $23,3 \%$ (7) balita, diantaranya adalah 5 balita tidak ada tanda phlebitis karena dilakukan tindakan pembidaian tempat pemasangan intravena, sebanyak 1 balita kemungkinan tanda dini phlebitis dan 1 balita dengan stadium permulaan phlebitis. Sedangkan balita yang berjalan sendiri ke toilet, sebanyak $3,3 \%$ (1) balita kemungkinan terjadi tanda dini phlebitis, dan sebanyak 13,3\% (4) balita tidak ada tanda phlebitis karena dilakukan tindakan pembidaian tempat pemasangan intravena serta lama pemasangan intravena adalah 2 hari. Menurut pendapat Macqueen, Bruce, \& Gibsonada (2012:421) menyatakan bahwa aktivitas anak atau manipulasi anak dapat berkontribusi peningkatan phlebitis, seperti anak berjalan dengan letak kanula di kaki. Data hasil penelitian tersebut menunjukkan bahwa, aktivitas balita yang menggunakan banyak pergerakan ekstremitas seperti berjalan sendiri ke toilet dan naik turun tempat tidur dapat mempengaruhi terjadinya dampak terapi intravena. Aktivitas yang kurang terkontrol, terutama pada tangan dapat menyebabkan tempat pemasangan terapi intravena menjadi tidak stabil. Sehingga intravena yang terpasang dapat terjadi pergeseran atau ketidak lancaran aliran cairan intravena. Karena itu aktivitas balita yang menggunakan ekstremitas yang terpasang intravena harus diminimalkan.

\section{Tindakan Pembidaian Tempat Pemasangan Intravena Dengan Dampak Terapi Intravena}

Berdasarkan hasil penelitian tindakan pembidaian tempat pemasangan intravena pada balita didapatkan hasil bahwa sebanyak 83,3\% (25) balita dilakukan tindakan pembidaian tempat pemasangan intravena, dan sebanyak $16,7 \%$ (5) balita tidak dilakukan tindakan pembidaian tempat pemasangan intravena. Sedangkan balita yang menunjukkan terdapatnya dampak terapi intravena yaitu sebanyak 2 balita yang kemungkinan tanda dini phlebitis tidak dilakukan tindakan pembidaian tempat pemasangan intravena, dan 1 balita dengan stadium permulaan phlebitis dilakukan tindakan pembidaian tempat pemasangan intravena. Menurut pendapat Macqueen, Bruce, \& Gibsonada (2012:421) menyatakan bahwa fiksasi yang buruk memungkinkan terjadinya gerakan kanula seperti bergesekan dengan dinding pembuluh darah. Tindakan pembidaian tempat pemasangan intravena dilakukan untuk mempertahankan kestabilan posisi intravena. Fiksasi yang kurang rapi dan kurang kuat, mengakibatkan tempat penyisipan intravena mudah tergoyahkan dan memungkinkan terjadinya gesekan antara jarum intravena dengan vena. Hal tersebut dapat menimbulkan tanda gejala dari dampak terapi intravena, sehingga mengganggu kenyamanan balita serta pemberian obat yang melalui terapi intravena tidak maksimal.

\section{SIMPULAN DAN SARAN Simpulan}

Dampak terapi intravena pada balita berdasar VIP (Visual Infusion Phlebitis) score didapatkan data sebanyak 27 balita dengan skor 0 ditandai dengan keadaan tempat penusukan intravena tampak sehat yang menunjukkan bahwa tidak ada tanda phlebitis, sebanyak 2 balita dengan skor 1 ditandai dengan terdapat nyeri tempat penusukan intravena yang menunjukkan kemungkinan tanda dini phlebitis, dan 1 balita dengan skor 2 ditandai dengan nyeri tempat penusukan intravena serta terdapat pembengkakan yang menunjukkan stadium permulaan phlebitis. Selain itu hasil penelitian ini menunjukkan bahwa pendokumentasian 
dampak terapi intravena menggunakan VIP (Visual Infusion Phlebitis) score tidak efektif jika dilakukan pada hari pertama dan kedua pemasangan terapi intravena

Saran

Bagi institusi pendidikan diharapkan dapat digunakan sebagai tambahan sumber informasi atau literatur tentang dampak terapi intravena yang terjadi pada balita sehingga dapat bermanfaat untuk proses kegiatan belajar mengajar. Bagi instansi kesehatan dapat digunakan sebagai acuan dalam meningkatkan pelayanan kesehatan, serta petugas kesehatan melakukan kegiatan pendokumentasian terhadap terjadinya dampak terapi intravena pada balita. Bagi peneliti selanjutnya diharapkan kepada peneliti selanjutnya untuk melakukan penelitian pada balita yang mendapat terapi intravena seperti tindakan pencegahan yang dilakukan petugas kesehatan untuk meminimalkan terjadinya dampak terapi intravena

\section{DAFTAR RUJUKAN}

Aprillin, H. 2011.Hubungan perawatan infus dengan terjadinya phlebitis pada pasien yang terpasang infus di Puskesmas Krian Sidoarjo, (Online),

(http://www.dianhusada.ac.id/jurnalimg/jur per 1-2-het.pdf), diakses 8 Oktober 2013.

Brunner \& Suddarth. 2002. Keperawatan Medikal-Bedah Volume 1. Jakarta: EGC

Darmadi. 2008. Infeksi Nosokomial Problematika dan Pengandaliannya. [ebook]. Jakarta: Salemba Medika http://books.google.co.id/books?id=BdkO Haf5RIC\&printse $c=$ frontcover $\# \mathrm{v}=$ onepage $\& \mathrm{q} \& \mathrm{f}=$ false. Diakses tanggal 23 November 2013

Notoatmodjo, S. 2010. Pendidikan Dan Perilaku Kesehatan. Jakarta: Rineka Cipta

Nur, Noor, \& Irwandi. 2013. Relationship Between Motivation And Supervision On Association Nurse Performance In Applying Patient Safety At Inpatient Ward Of Hasanuddin University Hospital In, (Online), (http://www.Qalbia $M$. Nur_Hubungan Motivasi Supervisi_140623.pdf), diakses tanggal 20 Desember 2013. 